\title{
Vertical Expansion Stability of an Existing Landfill: A Case Study of a Landfill in Xi'an, China
}

\author{
Hui Sheng $\mathbb{D},{ }^{1}$ Yinbang Ren $\mathbb{D},{ }^{1}$ Man Huang $\mathbb{D},{ }^{1}$ Zhenying Zhang $\mathbb{D},{ }^{2}$ and Jiwu Lan $\mathbb{D}^{3}$ \\ ${ }^{1}$ School of Civil Engineering, Shaoxing University, Shaoxing 312000, China \\ ${ }^{2}$ School of Civil Engineering and Architecture, Zhejiang Sci-Tech University, Hangzhou 310018, China \\ ${ }^{3}$ School of Civil Engineering and Architecture, Zhejiang University, Hangzhou 310012, China \\ Correspondence should be addressed to Zhenying Zhang; zhangzhenyinga@163.com
}

Received 6 February 2021; Revised 28 May 2021; Accepted 29 June 2021; Published 8 July 2021

Academic Editor: Xuemei Liu

Copyright $\odot 2021$ Hui Sheng et al. This is an open access article distributed under the Creative Commons Attribution License, which permits unrestricted use, distribution, and reproduction in any medium, provided the original work is properly cited.

\begin{abstract}
The vertical expansion of existing landfills can hold significant amounts of domestic waste and solve practical difficulties such as local government site selection. This research topic has become increasingly popular in the field of environmental geotechnical engineering. This study examined vertical expansion stability of landfills considering high leachate water level. The results showed the following. (1) Four slope instability modes for landfill vertical expansion are categorized according to the following slip surface positions: shallow slippage of the existing landfill, shallow slippage of the expanding landfill, interface slip between the existing landfill and expanding landfill, and deep slippage passes through the foundation soil. (2) The factor of safety decreases as the height of leachate level increases. When the height of leachate level rises from $2 \mathrm{~m}$ to $20 \mathrm{~m}$, the factor of safety of the landfill is reduced by $13.2-15.4 \%$. (3) As the vertical expansion height increases, the factor of safety of the existing landfill decreases, and when the expansion height increases to $30 \mathrm{~m}$, the stability factor of safety of the old waste landfill is reduced by $4.83 \%$. A landfill in Xi'an is considered as an example for the analysis, which shows that a leachate drainage layer can discharge leachate from the landfill body efficiently, reduce the leachate level height of the landfill body, and improve the stability of vertical expansion of the landfill. This study and its findings can be used as a reference for similar expansion projects.
\end{abstract}

\section{Introduction}

Since the 1980s, with the development of Chinese society and economy and the expansion of urban population, municipal solid waste (MSW) has increased substantially. Some economically developed cities began building China's first sanitary MSW landfills [1]. These landfill operations generally follow relatively simple methods, and most have been operating for more than ten or 20 years. Some of them have already constructed a second-phase landfill and are nearly occupied with sealed landfills. The $21^{\text {st }}$ century has witnessed a rapid growth in urban population, with subsequent rapid increase in MSW. There is an urgent need to build a new landfill to store and manage MSW. However, due to urban land scarcity, especially in densely populated cities, land is extremely limited. It is challenging to construct a new landfill to handle increased MSW. Therefore, the expansion of existing landfills is of great significance for protecting land resources [2]. Moreover, vertical expansion necessitates enhanced requirements for landfill stability.

Landfill stability is closely related to the engineering behavior of MSW. For example, assessing the stability of landfill slopes requires an understanding of the shear strength of MSW [3-6]. In addition, the expansion of a landfill may lead to the settlement of the existing landfill and expanded landfill, which may cause problems with the liner system and slope stability [7].

Roche [8] conducted on-site monitoring and finite element analysis on the soft, sensitive silty clay foundation soils, which confirmed the feasibility of vertical expansion on the existing landfill. Tieman et al. [9] considered the bottom liner and existing side slope grades, interface friction angles, type, and orientation of the geosynthetics relative to grade, and depth of leachate in the drainage layer above the 
piggyback liner system, using the computer program STABL, written at Purdue University, using Modified Bishop's and Simplified Janbu methods to analyze the stability of the vertical expansion landfill. Chen et al. [10] proposed the three-part wedge limit equilibrium method for landfill expansion, considering horizontal seismic force and analyzing the seismic stability of landfill. The results showed that landfill expansion is more likely to occur from seismic loads, and the extended landfill was more likely to slide along the interface between the new landfill and the old landfill under seismic loads. Choudhury and Savoikar [11] used a pseudostatic limit equilibrium method to consider the impact of horizontal and vertical seismic acceleration and analyzed the seismic stability of the vertical expansion landfill. The results showed that the average factor of safety decreased as both horizontal and vertical seismic accelerations increased. Rong et al. [12] used Qizishan landfill expansion project as an example to numerically simulate the stability of the existing landfill. The results showed that improving the strength of the landfill soil, establishing a good leachate guide exhaust system, controlling the leachate liquid level, and selecting a reasonable landfill elevation and gradient can ensure the stability of the vertical expansion of a landfill. Houlihan et al. [13] used the limit equilibrium method for the expansion of the Cherry Island Landfill to calculate slope stability and used SLIDE software to analyze the stability factor of safety. Ruan et al. [14] used the pseudodynamic method to calculate the factor of safety for the expanded landfill with a trapezoidal shape based on the slope failure conditions and found that the factor of safety decreased with the increase of the amplification factor. This showed that reasonable consideration of the magnitude of the amplification factor would be conducive to the seismic design of the landfill. Khoury et al. [15] evaluated the feasibility of increasing an existing landfill vertical height by 145 feet through geotechnical investigations, engineering analysis, and finite element method analysis to determine the stability of the vertically expanded landfill. Many scholars apply geosynthetics, reinforced soil, and reinforced walls to the vertical expansion of the landfill, which can improve the stability of the landfill. Chen et al. [16] found that when the thickness of the expansion pile is less than $40 \mathrm{~m}$, a two-layer high-strength geogrid can generally meet the design requirements of the vertical expansion landfill. Ke et al. [17] took the Xingfeng Vertical Extension Landfill in China as an example and adopted a geogrid to improve the stability of the eastern slope. Koda et al. [18] discussed a case study of an old MSW landfill in Poland and proposed reinforcing the landfill slope with a geogrid, geocomposite, and berms to improve the stability of the vertical expansion of the landfill; they used the limit equilibrium method to analyze the stability of the landfill. Gupta et al. [19] used the limit equilibrium method to calculate the slope stability of the original waste slope and the waste slope strengthened with reinforced soil and found that factor of safety of the existing landfill could reach 1.5 after the reinforcement of the waste slope with reinforced soil. Munwar Basha et al. [20] proposed applying reinforced soil berm (RSB) to the vertical expansion of an existing MSW landfill; they used the limit equilibrium method and assumed three-wedge failure mechanism to evaluate the stability of the RSB and compute the optimum dimensions of RSB. Mahapatra [21] used reinforced soil wall (RSW) for vertical expansion of MSW landfills and presented a methodology to evaluate the safe seismic design of RSW for a vertical expansion of landfill under six different leachate build-up conditions. Mahapatra et al. [22] proposed that a system reliability framework for the design of mechanically stabilized earth (MSE) walls should be applied to the vertical expansion of the MSW landfill. When the landfill was expanded vertically, the minimum ratio of the length of the geosynthetic reinforcement to the height of the MSE walls should be increased above 0.6 for the MSE walls to perform satisfactorily.

During vertical expansion, an intermediate liner system containing a variety of geosynthetics should be installed at the interface of the new landfill and old landfill as an impermeable barrier for the expansion pile [7]. Although this intermediate liner system provides good impermeability, the shear strength of the clay-geomembrane and geomembranegeotextile interface is low, which can result in sliding along the liner interface and damage to the expanded landfill [23]. Gao et al. [24] proposed that the deformation of the intermediate liner system could be reduced by vibration compaction, lowering the leachate level, setting folds, and laying flexible geomembrane. Zhan et al. [25] improved slope liner configuration systems, established a three-dimensional drainage system to reduce the leachate level, raised the height of the downstream retaining dam, and established a safety monitoring system, which can fill the landfill to a design elevation of $130 \mathrm{~m}$. Tano et al. [26] studied the numerical simulation of nonlinear mechanical behavior of various geosynthetics for vertical expansion intermediate liners in landfills. Qian et al. [27] used a geosynthetic clay liner (GCL) instead of a compacted clay liner (CCL) for the vertical expansion of a landfill. Jiang et al. [28] proposed the design of a geosynthetic reinforced embankment, which can be used as a reference for landfill expansion.

However, limited studies exist which consider the leachate level $[6,12]$. Due to the high organic waste content and high yield of leachate in Chinese landfills, it is difficult to effectively drain leachate only through the drainage system at the bottom of the reservoir. The leachate that cannot be drained is retained in the body of the landfills, resulting in high leachate levels $[29,30]$. Vertical expansion of a landfill needs to control the leachate level of the existing landfill. It is difficult to manage leachate drainage only by the guide and drainage system at the bottom of a landfill. It must be ensured that leachate drainage facilities can be continuously drained after the closure of the landfill [31]. Leachate drainage facilities could also be built in the landfill body to reduce the leachate level so that the existing landfill can meet the expansion stability requirements.

The most commonly used engineered leachate drainage facilities mainly include vertical wells $[32,33]$ and horizontal trenches [34]. Lan [29] used the Seep/W model to analyze horizontal trenches, which effectively reduced the leachate level and pressure head in the simulation unit. Ye et al. [34] studied the spacing design, established a seepage model of a 
horizontal trench, and identified the relationship between the design spacing and corresponding warning water level for the landfill stability control requirements. The drainage layer effectively reduced the leachate level of the landfill $[35,36]$.

This study analyzes the problems existing in landfill vertical expansion and examines the instability modes of landfill vertical expansion. Using GeoStudio software, the Morgenstern-Price limit equilibrium method is used to calculate factor of safety of the landfill and analyze the stability of the vertical expansion of the landfill. A landfill site in Xi'an, China, was selected as the case study. Considering its high leachate level, the drainage layer was installed during the vertical expansion of the landfill. The drainage layer was then evaluated based on surface horizontal displacement, deep lateral displacement, and leachate level. The drainage layer applies to the stability control effect of the vertical expansion, evaluates the subsequent filling height, and guides the stability analysis in vertical expansion of the landfill.

\section{Materials and Methods}

2.1. MSW Composition. The MSW used in this study is from a landfill in Xi'an, China. The composition of the waste is detailed in Figure 1, where Figure 1(a) shows the composition of the existing landfill waste [37], and Figure 1(b) shows the composition of the expanding waste [38]. Figure 1 shows that the existing landfill waste contained organic waste $(47.8 \%)$, plastic $(31.1 \%)$, paper $(3.9 \%)$, wood $(3.8 \%)$, and others (13.4\%); and the expanding landfill waste contained organic waste $(56.9 \%)$, plastic $(12.1 \%)$, paper $(8.9 \%)$, textiles $(2.5 \%)$, wood (1.9\%), and others (17.7\%). Organic waste is the dominant component; the proportion of plastics in the existing landfill waste is $19 \%$ higher than that in the expanding landfill waste, and the proportions of other components such as paper, wood, and textiles are approximately equal.

2.2. Shear Strength Parameters of MSW. Shear strength is the basic parameter in the stability calculation of geotechnical engineering. The shear strength of MSW is usually described by the Mohr-Coulomb failure criterion commonly used in geotechnical engineering [39], and the shear strength calculation is represented as follows:

$$
\tau_{f}=c+\sigma \tan \varphi,
$$

where $\tau_{f}$ is the shear strength of MSW, $\sigma$ is the normal stress, $c$ is the cohesion, and $\varphi$ is the internal friction angle. The landfill shear strength parameters are key parameters in determining the landfill stability and ensuring its stable operation. Considering the high leachate level in Xi'an landfill, the consolidation undrained shear test is used to determine the shear strength parameters of the waste. The shear strength parameters of the waste [40] are listed in Table 1, which shows that the cohesion of the expanding landfill waste is greater than that of the existing landfill waste, and the angle of internal friction is smaller than that of the existing landing waste.
2.3. Analysis Method. The limit equilibrium method is also known as vertical strip method. This method divides the landslide body into a series of strips with vertical interfaces and uses soil strips and the whole static balance or the moment equilibrium equation to calculate factor of safety of the slope. The traditional limit equilibrium methods include the Bishop method [41], Spencer method [42], and Morgenstern and Price method [43]. Table 2 lists the different methods used by scholars with increasing research on landfill stability analysis. The methods, on the basis of the traditional limit equilibrium method, included the wedge limit equilibrium method [44], three-part wedge limit equilibrium method [45], simplified Bishop [46], and other methods to meet specific conditions.

\section{Vertical Expansion Stability}

3.1. Expansion Method. The common expansion modes include vertical, horizontal, and compound expansion [66]. Vertical expansion is also called "piggyback" [67], which refers to continuing to pile and add waste on top of the existing landfill waste. Examples of this method are observed at a landfill site in Peabody, MA [67], the Cherry Island Landfill in Delaware [13], and the Quarantine Road Landfill in Maryland [15]. A landfill in Xi'an, China, is used for the vertical expansion case study presented in this article. It is a valley-type vertical expansion project with a vertical elevation of $30 \mathrm{~m}$ on the existing landfill (Figure 2).

3.2. Problems with Expansion. Vertical expansion introduces additional problems, such as landfill settlement, the migration and diffusion of leachate, and the stability of the landfill [66].

(1) Under the forces of self-compression, mechanical creep, biodegradation, and vertical expansion of the landfill load, the existing landfill body can experience significant settling. Landfill age, composition, and depth also contribute to settlement in different areas in the old landfill site, resulting in uneven settlement of the existing landfill. The vertical expansion will lead to large settlement and uneven settlement of the old landfill, which will change the slope of the intermediate liner system at the junction of the new landfill and old landfill.

(2) Due to the large and uneven settlement of the old landfill, the leachate drainage system slope at the junction of the new landfill and old landfill changes and even produces a reverse slope. This obstructs the drainage, thereby causing an increased leachate head and subsequently increasing the landfill body instability risk. Vertical expansion has increased the lateral deformation of the slope area of the old landfill, causing the intermediate liner system to generate a certain additional tensile strain. This may cause tensile failure of the impermeable material and lead to an impermeability failure and generate continuing secondary pollution to surrounding water and soil [68]. 


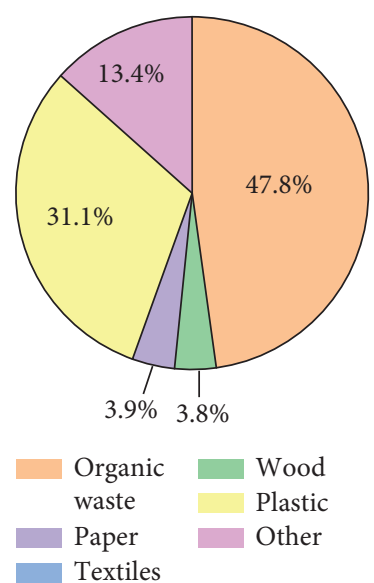

(a)

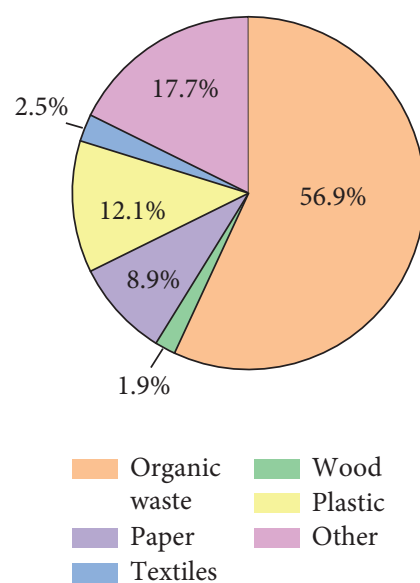

(b)

FIgURE 1: Municipal solid waste components in the landfill. (a) Existing landfill waste. (b) Expanding landfill waste.

TABLE 1: Shear strength parameters of municipal solid waste.

\begin{tabular}{lcc}
\hline Landfill waste & $c(\mathrm{kPa})$ & $\varphi\left(^{\circ}\right)$ \\
\hline Existing landfill waste & $4-9$ & $15-26$ \\
Expanding landfill waste & $9.5-12$ & $5-14$ \\
\hline
\end{tabular}

TABLE 2: Research methods on landfill stability analysis.

\begin{tabular}{|c|c|c|}
\hline Time & Scholars & Methods \\
\hline 2000 & Stark et al. [47] & Limit equilibrium method \\
\hline 2003 & Qian et al. [44] & $\begin{array}{l}\text { Double-wedge analysis method } \\
\text { Limit equilibrium method }\end{array}$ \\
\hline 2004 & Liu and Kong [48] & Discontinuous deformation analysis \\
\hline 2004 & Wang et al. [49] & Limit equilibrium method \\
\hline 2006 & Durmusoglu et al. [50] & Numerical calculation method \\
\hline 2007 & McDougall [51] & Finite element method \\
\hline 2007 & Feng et al. [45] & Three-part wedge limit equilibrium method \\
\hline 2008 & Chen et al. [10] & Three-part wedge limit equilibrium method \\
\hline 2008 & Machado et al. [52] & Numerical calculation method \\
\hline 2008 & Bauer et al. [53] & Numerical calculation method \\
\hline 2009 & Hossain and Haque [4] & Limit equilibrium method \\
\hline 2009 & Qian and Koerner [54] & Three-part wedge limit equilibrium method \\
\hline 2010 & Zhang et al. [55] & Limit equilibrium Bishop method \\
\hline 2010 & Turer and Turer [56] & Numerical calculation method \\
\hline 2011 & Varga [57] & Limit equilibrium method \\
\hline 2013 & Basha and Mahapatra [58] & Limit equilibrium method \\
\hline 2013 & Shi and Luan [59] & Limit equilibrium method \\
\hline 2013 & Sun and Ruan [60] & Pseudostatic limit equilibrium method \\
\hline 2014 & Giri and Reddy [61] & Numerical calculation method \\
\hline 2014 & Zhang et al. [62] & Finite element method \\
\hline 2016 & Ering and Sivakumar Babu [5] & Limit equilibrium method \\
\hline 2016 & Fan et al. [63] & Limit analysis upper limit method \\
\hline 2017 & Batali et al. [64] & Numerical calculation method \\
\hline 2017 & Jahanfar et al. [65] & Probabilistic risk assessment \\
\hline 2018 & Gao et al. [6] & Limit equilibrium method \\
\hline
\end{tabular}

(3) The stability of vertically expanded landfill depends on the stability of the old landfill, new landfill, and the interface between the expanded landfill and existing landfill.
Before performing the stability analysis, it is necessary to study the vertical expansion failure modes $[46,54]$. According to the position of the slip surface of the vertical expansion landfill, the instability can be divided into the four following modes: 


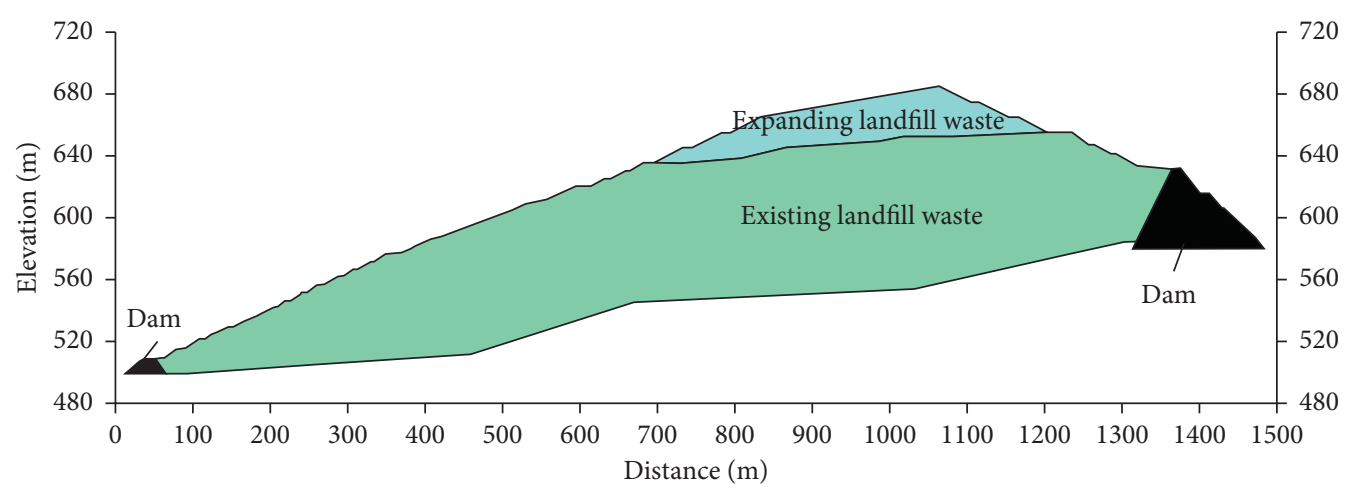

FIgure 2: Vertical expansion profile of the Xi'an landfill.

(1) Shallow slippage of the existing landfill (Figure 3(a)).

(2) Shallow slippage of the expanding landfill (Figure 3(b)).

(3) Interface slip between the existing landfill and expanding landfill (Figure 3(c)). Due to the low shear strength of the interface liner, the landfill slides along the liner interface.

(4) Deep slippage passing through the foundation soil (Figure 3(d)). As the foundation soil cannot resist the gravity and shear forces of the existing landfill MSW and the expanding MSW, the slip surface slips through the weak foundation soil when it loses stability.

There are generally four slope instability modes in the vertical expansion of the landfill. Modes (a) and (b) occur in the shallow slope of the landfill. In addition to factors such as the aspect ratio and shear strength parameters of the slope pile, it is also related to the height of the leachate level. The excessively high leachate water level in landfill sites will increase pore water pressure and reduce the shear strength of MSW, which can create instability and slip [69]. The vertical expansion of the existing landfill is a dynamic landfill process. The stress conditions of the existing landfill are constantly changing, causing uneven settlement in the existing landfill, which makes the interface between the expanding landfill and existing landfill an impermeable liner system. The slope change also increases the lateral deformation of the slope area of the existing landfill, causing the interface liner system to generate additional tensile stress, which may cause tensile failure of the liner material [68]. The geomembrane set in the liner interface can isolate the upper and lower garbage piles, but the geomembrane is relatively smooth, and its shear strength is very low. The vertical expansion of the waste piles readily loses stability and slips at the geomembrane interface, resulting in mode (c). For example, the Kettleman Landfill in the United States slips at the interface of the geomembrane [70,71]. The soft foundation has low shear strength, low bearing capacity, and high compressibility. Under the load of the existing and expanded waste dump, a large foundation settlement occurs. Therefore, on soft foundations, such as tidal flats and swamp soil, vertical expansion of the waste dump needs to include the consolidation settlement and horizontal slippage of the foundation soil. Mode (d) represents deep slippage, which causes significant harm, such as the Rumpke Landfill in the United States [72] and Meethotamulla Landfill in Sri Lanka $[73,74]$. This mode includes instability due to insufficient foundation bearing capacity.

3.3. Stability Analysis. The SLOPE/W module in GeoStudio (GEOSLOPE International Ltd, Canada) is used to establish the corresponding geometric model, and the MorgensternPrice limit equilibrium method is used for stability analysis. The corresponding model is established for the calculation of different soil layers, sliding surface shapes, and various pore water pressure conditions. The minimum factor of safety $(F s)$ is used to determine the vertical expansion stability.

The landfill length is set to $300 \mathrm{~m}$, and the MSW to be landfilled is divided into existing landfill waste and expanding landfill waste. The top surface average gradient of the existing landfill is approximately $5 \%$, landfill slope ratio is $1: 3$, base thickness is $20 \mathrm{~m}$, and vertical expansion is $30 \mathrm{~m}$. The material parameters of the landfill are presented in Table 3. To analyze the influence of different leachate level heights on the stability of the landfill, the leachate level height is set to $2 \mathrm{~m}, 4 \mathrm{~m}, 6 \mathrm{~m}$, $8 \mathrm{~m}, 10 \mathrm{~m}, 15 \mathrm{~m}$, and $20 \mathrm{~m}$ from the liner system to calculate the overall $F s$ of the existing and the vertically expanded landfills. The calculation results are presented in Table 4.

Table 4 shows that $F s$ decreases with an increase in the leachate level. When the leachate level increases from $2 \mathrm{~m}$ to $20 \mathrm{~m}$, the overall factor of safety of the landfill decreases by 13.2 to $15.4 \%$. Fs decreases as the height of the vertical expansion increases. When the vertical expansion height increases from $0 \mathrm{~m}$ to $30 \mathrm{~m}, F s$ decreases by 3.5 to $7.7 \%$. The change range of $F s$ is significantly influenced by the changes in leachate level but is minimally impacted by changes in the vertical expansion height.

When the leachate level increases to $8 \mathrm{~m}$, the vertical expansion of the $30 \mathrm{~m}$ landfill is in an unstable state (Figure 4), which is the instability mode of deep slippage passing through the foundation soil.

To analyze the influence of different vertical expansion heights on the stability of the existing landfill, the vertical expansion heights are set to $10 \mathrm{~m}, 20 \mathrm{~m}$, and $30 \mathrm{~m}$; the leachate level of the existing landfill is $0.3 \mathrm{~m}$. The results are presented in Table 5. 


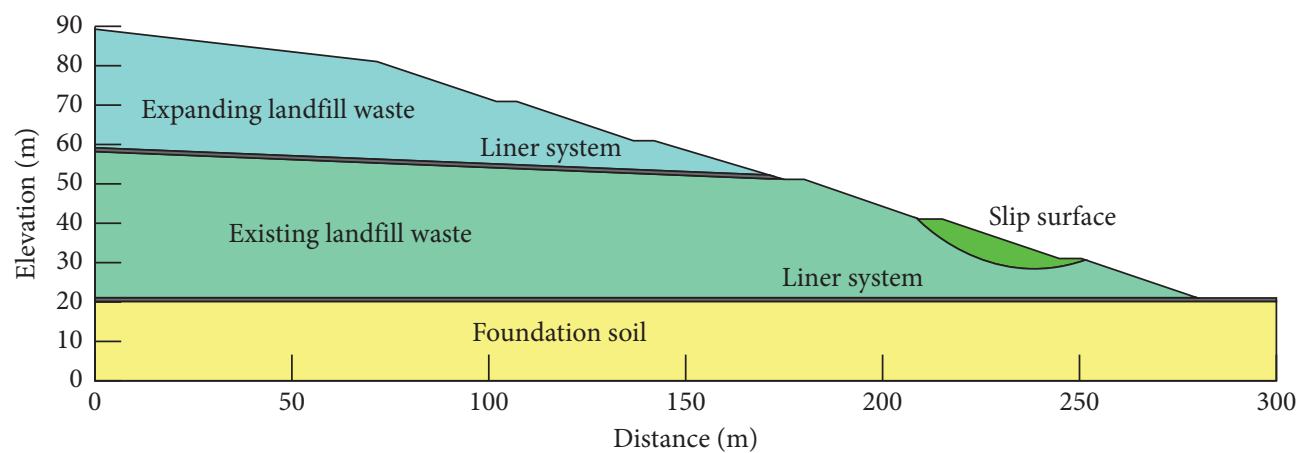

(a)

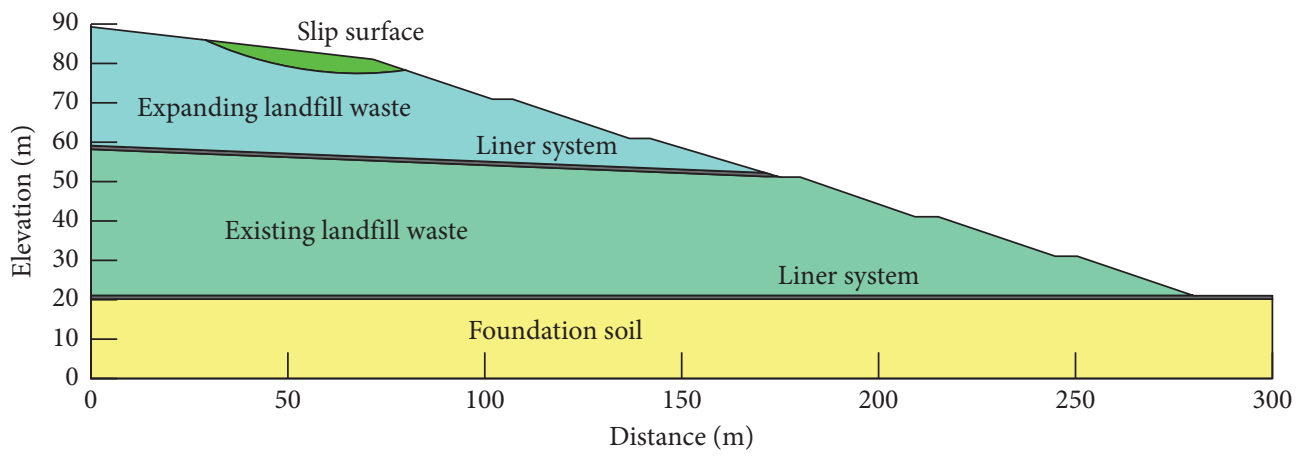

(b)

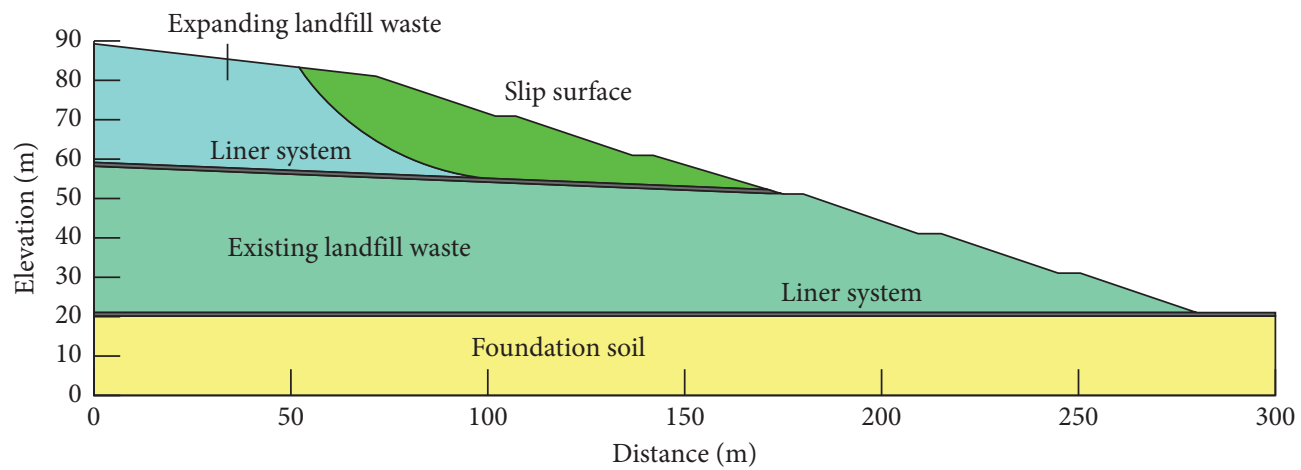

(c)

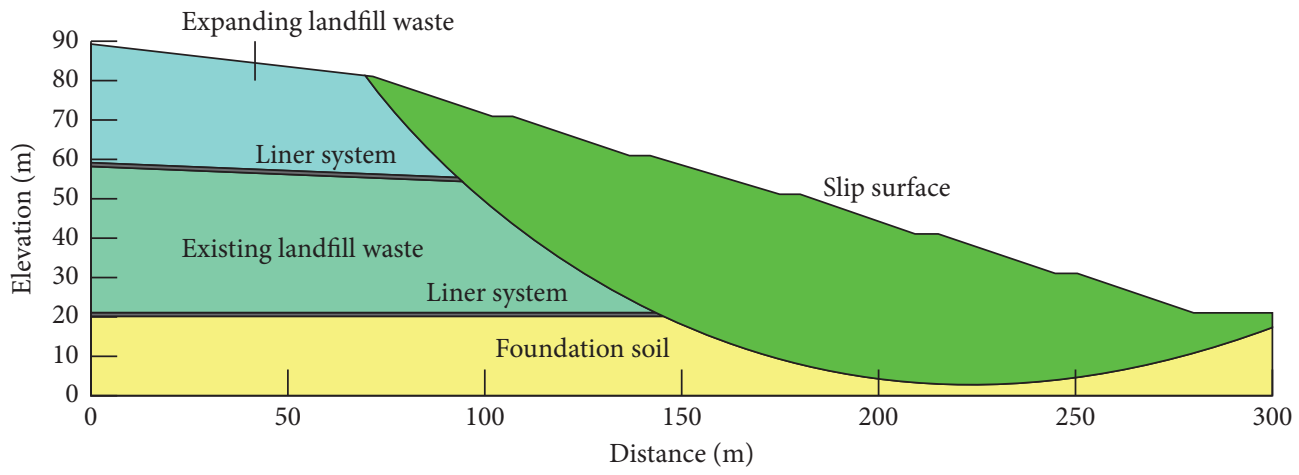

(d)

FIgURE 3: Landfill instability modes of vertical expansion. (a) Shallow slippage of the existing landfill. (b) Shallow slippage of the expanding landfill. (c) Interface slip between the existing landfill and the expanding landfill. (d) Deep slippage passes through the foundation soil.

Table 5 shows that the vertical expansion of the existing landfill by $10 \mathrm{~m}$ reduces $F s$ of the landfill by 0.033 . The vertical expansion of the existing landfill by $20 \mathrm{~m}$ reduces $F s$ of the landfill by 0.055 . The vertical expansion of the existing landfill for $30 \mathrm{~m}$ reduces $F$ s of the landfill by 0.074 and $4.83 \%$. 
TABLE 3: Shear strength parameters for materials.

\begin{tabular}{lccc}
\hline Material & Unit weight, $\gamma\left(\mathrm{kN} / \mathrm{m}^{3}\right)$ & Cohesive force, $c(\mathrm{kPa})$ & Internal friction angle, $\varphi\left(^{\circ}\right)$ \\
\hline Expanding landfill waste & 12 & 10 & 12 \\
Existing landfill waste & 14 & 4 & 20 \\
Liner system & 10 & 3 & 21 \\
Foundation soil & 19 & 30 & 22 \\
\hline
\end{tabular}

TABLE 4: Factor of safety $(F s)$ of vertical expansion at different leachate levels.

\begin{tabular}{|c|c|c|c|c|}
\hline \multirow{2}{*}{ Leachate level height (m) } & \multicolumn{4}{|c|}{ Fs } \\
\hline & Existing landfill & Vertical expansion of $10 \mathrm{~m}$ & Vertical expansion of $20 \mathrm{~m}$ & Vertical expansion of $30 \mathrm{~m}$ \\
\hline 2 & 1.517 & 1.491 & 1.457 & 1.437 \\
\hline 4 & 1.455 & 1.432 & 1.419 & 1.403 \\
\hline 6 & 1.415 & 1.399 & 1.377 & 1.366 \\
\hline 8 & 1.390 & 1.375 & 1.353 & 1.319 \\
\hline 10 & 1.378 & 1.350 & 1.325 & 1.286 \\
\hline 15 & 1.328 & 1.305 & 1.270 & 1.231 \\
\hline 20 & 1.317 & 1.274 & 1.244 & 1.216 \\
\hline
\end{tabular}

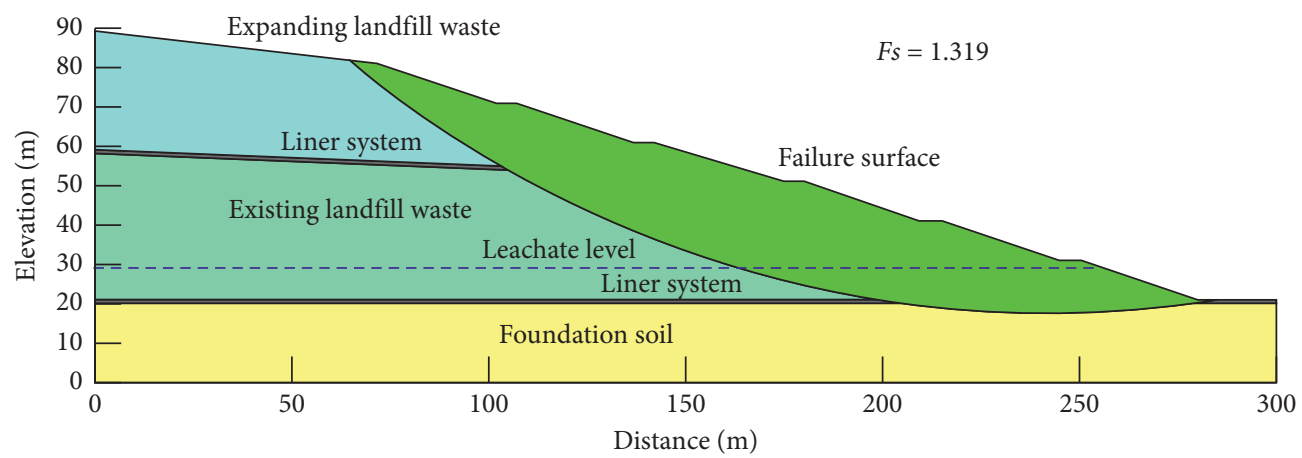

FIgURE 4: Failure surface with $30 \mathrm{~m}$ landfill vertical expansion with leachate level of $8 \mathrm{~m}$.

TABLE 5: Factor of safety $(F s)$ of different vertical expansion heights for the existing landfill when the leachate level is $0.3 \mathrm{~m}$.

\begin{tabular}{lc}
\hline Vertical expansion height $(\mathrm{m})$ & $F s$ \\
\hline 0 & 1.533 \\
10 & 1.500 \\
20 & 1.478 \\
30 & 1.459 \\
\hline
\end{tabular}

\section{Case Study}

4.1. Project Overview. The landfill in this study is an MSW terminal disposal site in Xi'an, China. It covers an area of greater than $0.73 \mathrm{~km}^{2}$ and has a total volume of greater than 49 million $\mathrm{m}^{3}$ (Figure 5). The landfill is a typical valley-type landfill that was built in a narrow valley in the Loess Plateau area. The upper and lower reaches of the valley bottom exceed $1000 \mathrm{~m}$, the valley bottom elevation ranges between $498 \mathrm{~m}$ and $546 \mathrm{~m}$, and the longitudinal slope is $3.52-15.7 \%$. The horizontal width of the flat section of the valley bottom is between $50 \mathrm{~m}$ and $100 \mathrm{~m}$, and the original slopes on both sides of the valley are approximately $1: 1$ at the steeper section and approximately $1: 3$ in the shallower section. The landfill started receiving waste in 1994 and has been continuously operating for 20 years. The average daily landfill volume has increased from the initial $1260 \mathrm{t} / \mathrm{d}$ to the current $10,000 \mathrm{t} / \mathrm{d}$, and the daily waste collection and transportation volumes have doubled. This far exceeds the designed landfill capacity, and the landfill has been operating in overload conditions for a long time. The landfill mainly receives layered landfill, gradually filling from the south of the landfill to the north. The thickness of each landfill layer is approximately $10 \mathrm{~m}$ with a total of 14 layers. Presently, two vertical expansion projects have been completed at the landfill with a maximum elevation difference of $155 \mathrm{~m}$, becoming the highest landfill slope in China. Subsequently, the existing landfill was vertically expanded by $30 \mathrm{~m}$ and filled in three times, with a landfill slope ratio of $1: 4$, and a $10 \mathrm{~m}$ wide platform was installed for each additional layer.

4.2. Stability Analysis. The model proposed in this paper was based on the topographic profile of the landfill in November 2019 (Figure 2), and the stability analysis parameters are listed in Table 3. To analyze how leachate level reduction affects landfill vertical expansion stability, the leachate level height was set at $3 \mathrm{~m}, 5 \mathrm{~m}, 10 \mathrm{~m}$, and $15 \mathrm{~m}$ from the top of the slope, and the factors of safety were calculated (Table 6). The 


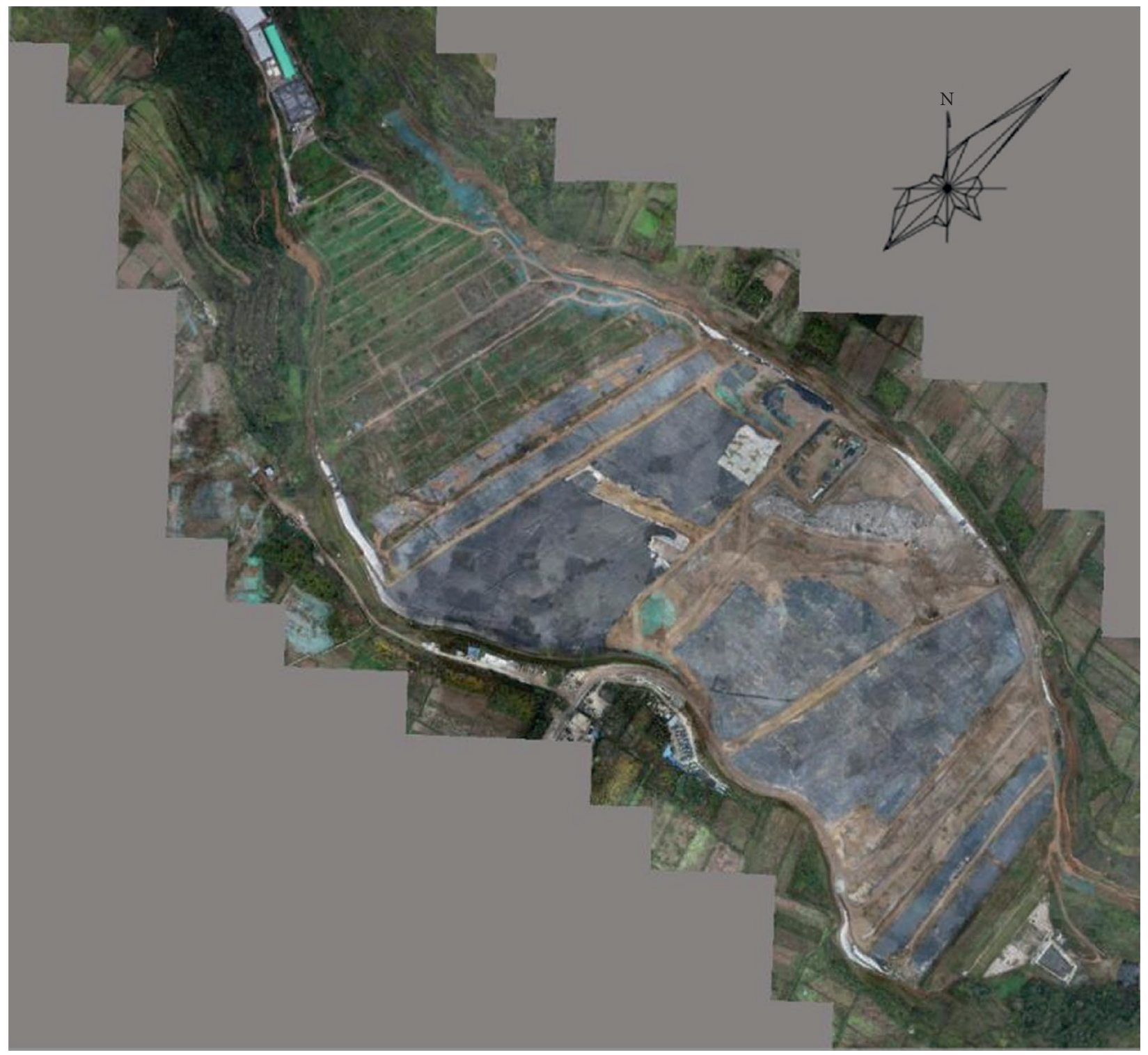

Figure 5: The Xi'an landfill by UAV.

TABLE 6: Factors of safety at different leachate levels relative to vertically expanded height.

\begin{tabular}{lcccc}
\hline $\begin{array}{l}\text { Height of leachate level from } \\
\text { surface }(\mathrm{m})\end{array}$ & $\begin{array}{c}\text { Existing } \\
\text { landfill }\end{array}$ & $\begin{array}{c}\text { Vertical expansion of } 10 \mathrm{~m} \\
\text { landfill }\end{array}$ & $\begin{array}{c}\text { Vertical expansion of } 20 \mathrm{~m} \\
\text { landfill }\end{array}$ & $\begin{array}{c}\text { Vertical expansion of } 30 \mathrm{~m} \\
\text { landfill }\end{array}$ \\
\hline 3 & 1.18 & 1.18 & 1.11 & 0.94 \\
5 & 1.25 & 1.21 & 1.17 & 0.99 \\
10 & 1.41 & 1.37 & 1.32 & 1.19 \\
15 & 1.58 & 1.53 & 1.47 & 1.45 \\
\hline
\end{tabular}

calculated results demonstrate that $F$ s decreases with an increase in vertical expansion height. When the leachate level height decreased by $5 \mathrm{~m}$, Fs increased by $12-22 \%$. When the leachate level height was set at $15 \mathrm{~m}, F$ s was greater than 1.35 , indicating that the landfill is in a stable state.
4.3. Monitoring Results and Analysis. To understand landfill stability during the vertical expansion process and the stability control effect of the leachate drainage layer application, follow-up monitoring was conducted. The locations of the monitoring points are shown in Figure 6. The monitoring of 


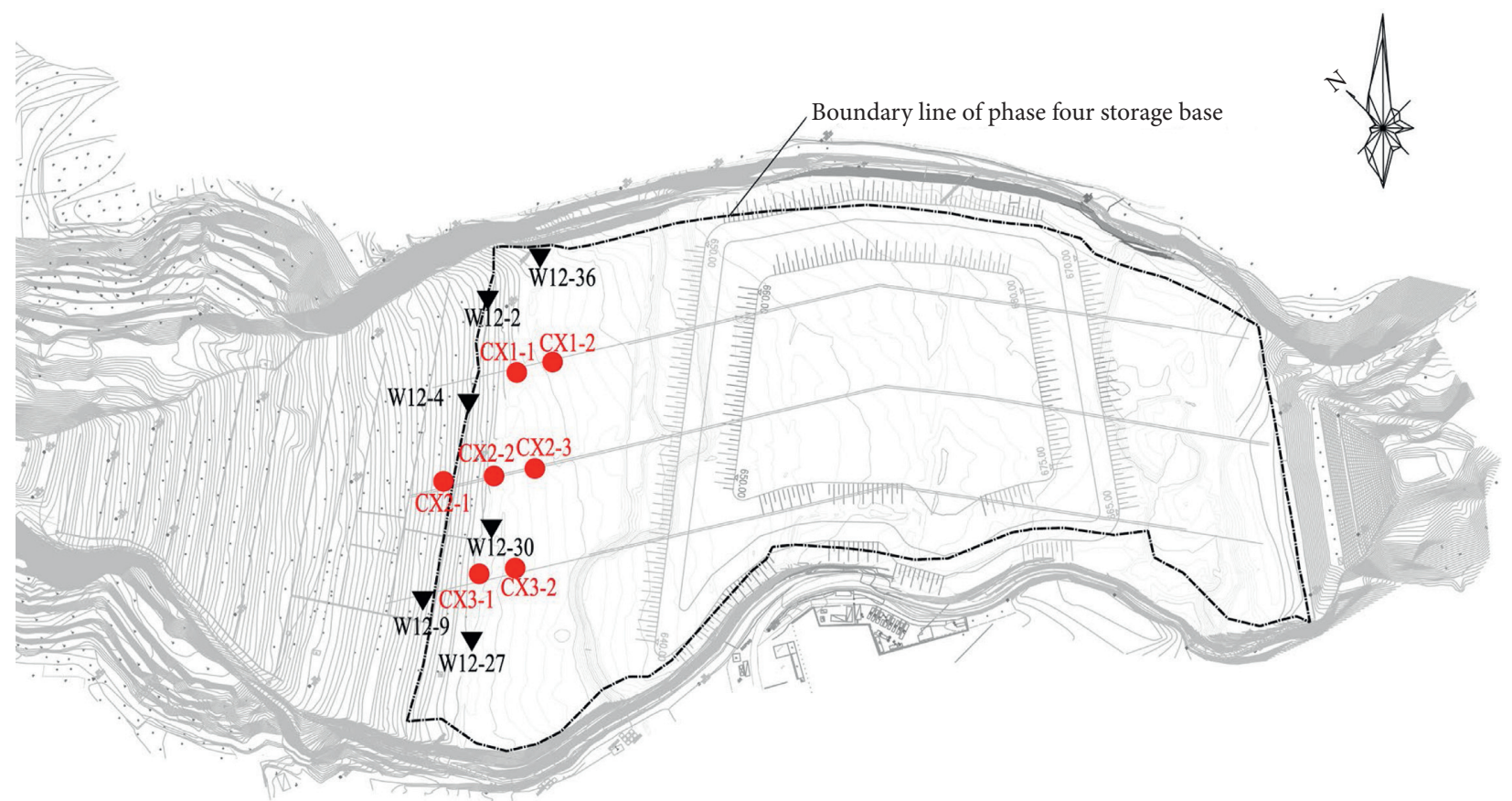

- CX Leachate level and the deep displacement monitoring hole

$\boldsymbol{\nabla} \mathrm{W}$ Surface displacement monitoring hole

FIgURE 6: The locations of the monitoring points.

surface horizontal displacement, deep lateral displacement, and leachate level monitoring was performed.

The construction of the leachate drainage layer was completed in December 2017, and the stability control effect was evaluated by comparing the horizontal displacement rate of each monitoring point with and without the leachate drainage layer. It is stipulated in geotechnical engineering code of MSW sanitary landfill that a warning is required when the surface displacement rate exceeds $10 \mathrm{~mm} / \mathrm{d}$ for two consecutive days. Figure 7 shows the monitoring results of the $12^{\text {th }}$ platform, where $W$ is the average daily surface displacement rate and the horizontal dotted line is the warning value. As shown in Figure 7, after the leachate drainage layer installation was completed in December 2017, the surface displacement rates of monitoring points at the bottom and top of the $12^{\text {th }}$ platform were significantly less than those from October to November 2017; neither exceeded the warning value. The maximum displacement rate at the bottom of the slope was $9.0 \mathrm{~mm} / \mathrm{d}$, which was $12 \%$ of the maximum displacement rate of the monitoring point in November 2017. The maximum displacement rate of the slope top was $9.9 \mathrm{~mm} / \mathrm{d}$, which was $26 \%$ of the maximum displacement rate of the monitoring point in November 2017.

4.4. Deep Lateral Displacement Monitoring. Three deep lateral displacement monitoring points, CX2-1, CX2-2, and CX2-3, located at the slope bottom and top of the $12^{\text {th }}$ platform and the slope top of the $13^{\text {th }}$ platform were selected. Monitoring results in Figure 8 show that CX2-3 experienced significant displacement from the ground to a depth of $17 \mathrm{~m}$ above the leachate drainage layer, and the maximum displacement rate reached $1.4 \mathrm{~mm} / \mathrm{d}$. This was significantly less than the displacement rate of the monitoring point under the leachate drainage layer. The maximum daily average displacement of $1.4 \mathrm{~mm} / \mathrm{d}$ at the top of the $13^{\text {th }}$ platform slope above the leachate drainage layer was $33 \%$ of the maximum daily average displacement of $4.3 \mathrm{~mm} / \mathrm{d}$ at the bottom of the $12^{\text {th }}$ platform slope below the leachate drainage layer. This was $50 \%$ of the maximum daily average displacement of $2.8 \mathrm{~mm} / \mathrm{d}$ at the top of the $12^{\text {th }}$ platform slope.

4.5. Leachate Level Monitoring. The buried leachate level monitoring points at the top of the $12^{\text {th }}$ and $13^{\text {th }}$ platforms were selected, and results are presented in Figure 9. Figure 9 shows that the leachate depths of CX1-1, CX2-2, and CX3-1 on top of the $12^{\text {th }}$ platform slope below the leachate drainage layer were $-5.1 \mathrm{~m},-5.8 \mathrm{~m}$, and $-6.0 \mathrm{~m}$, respectively. The buried depths of CX1-2, CX2-3, and CX3-2 on the top of the $13^{\text {th }}$ platform slope above the leachate drainage layer were $-12.8 \mathrm{~m},-5.7 \mathrm{~m}$, and $-8.8 \mathrm{~m}$, respectively. The existence of the drainage layer effectively reduced the leachate level, indicating that the drainage layer application had an effect on the vertical expansion stability of the landfill.

\section{Discussion}

Table 7 lists the vertical expansion indicators for different landfills, combining the expansion projects of a landfill in Xi'an, China, Qizishan landfill in Suzhou, China [12, 74], Tianziling landfill in Hangzhou, China [25], and Quarantine 


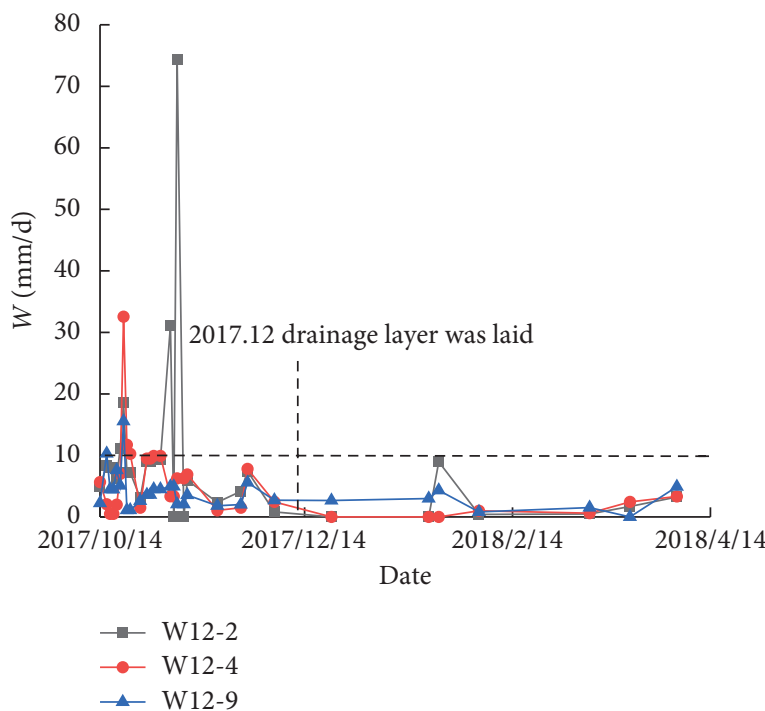

(a)

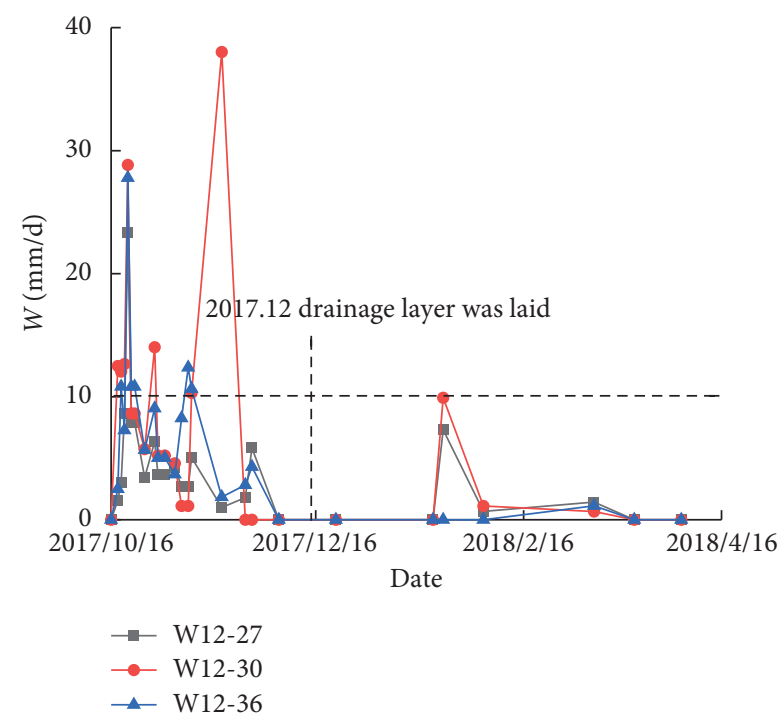

(b)

FIGURE 7: Monitoring results of surface horizontal displacement. (a) $12^{\text {th }}$ bottom of platform. (b) $12^{\text {th }}$ top of platform.

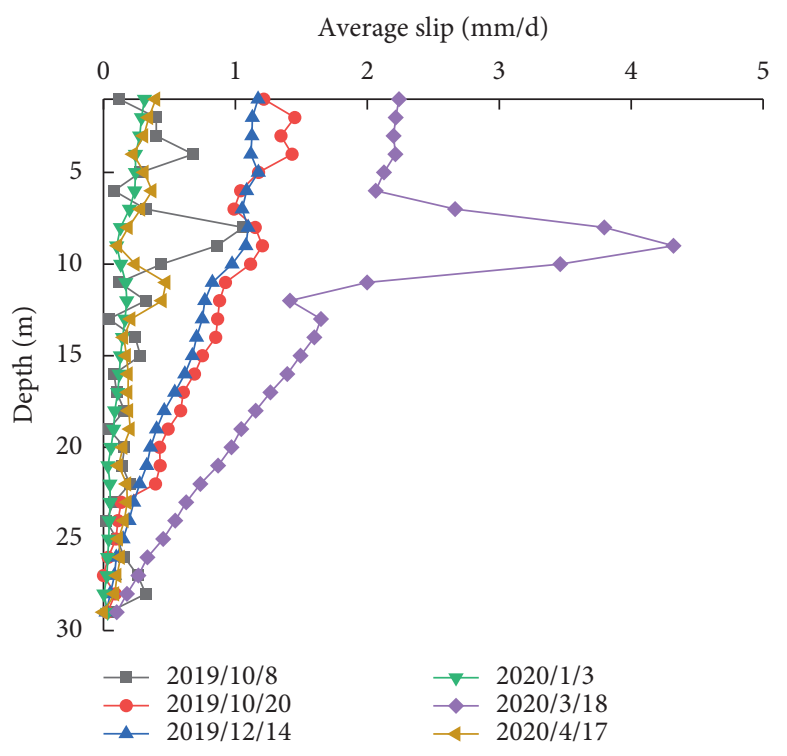

(a)

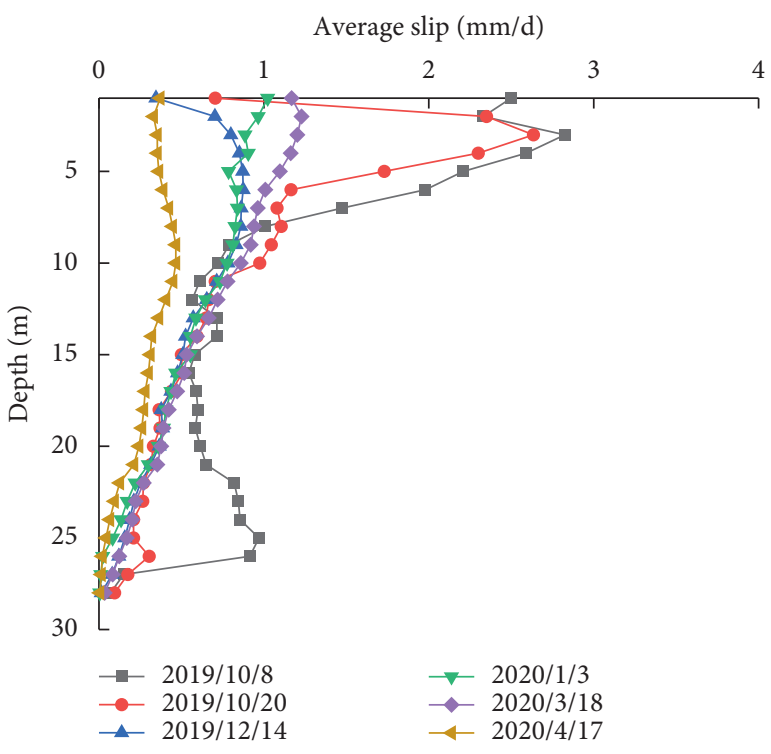

(b)

FIgURe 8: Continued. 


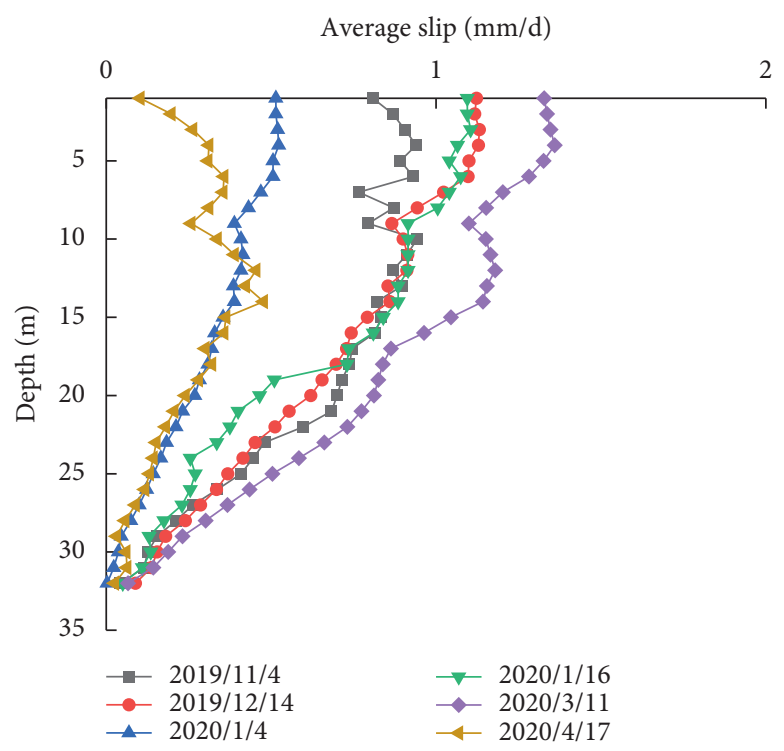

(c)

Figure 8: Monitoring results of deep lateral displacement. (a) CX2-1. (b) CX2-2. (c) CX2-3.

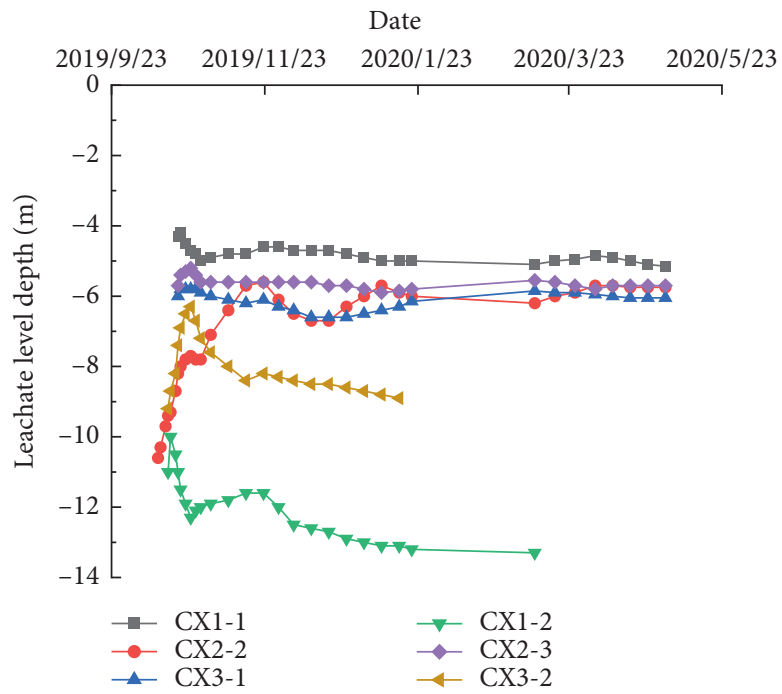

FIGURE 9: Monitoring results of leachate level depth.

TABLe 7: Comparison of different vertically expanded landfills.

\begin{tabular}{|c|c|c|c|c|c|c|c|}
\hline Landfill name & $\begin{array}{c}\text { Landfill } \\
\text { height }(\mathrm{m})\end{array}$ & $\begin{array}{c}\text { Vertical expansion } \\
\text { height }(\mathrm{m})\end{array}$ & Gradient & $\begin{array}{c}\text { Cohesive force, } \\
c(\mathrm{kPa})\end{array}$ & $\begin{array}{c}\text { Internal friction } \\
\text { angle, } \varphi\left({ }^{\circ}\right)\end{array}$ & $\begin{array}{c}\text { Leachate level } \\
\text { height }(\mathrm{m})\end{array}$ & Fs \\
\hline Xi'an landfill, China & 185 & 30 & $1: 4$ & $4-12$ & $5-26$ & 15 & 1.45 \\
\hline $\begin{array}{l}\text { Qizishan landfill, } \\
\text { China }\end{array}$ & 130 & 40 & $1: 3$ & $8-21.60$ & $9.60-29.50$ & 15 & 1.50 \\
\hline $\begin{array}{l}\text { Tianziling landfill, } \\
\text { China }\end{array}$ & 96.25 & 43.75 & $1: 4$ & $0-20$ & $25-36$ & $5-8$ & 1.35 \\
\hline $\begin{array}{l}\text { Quarantine Road } \\
\text { landfill, USA }\end{array}$ & 65.32 & 44.20 & $\begin{array}{c}1: 3-1: \\
25\end{array}$ & $0-4.79$ & $20-24$ & & $1.42-1.65$ \\
\hline
\end{tabular}

Road landfill in the United States [15]. To analyze landfill vertical expansion, the vertical expansion height, gradient, shear strength parameters, leachate level height, and Fs of the vertical expansion stability were compared. Table 7 shows that the landfill height of the Xi' an landfill in China is $155 \mathrm{~m}$, which has become the tallest landfill in China. Increased 
waste loading causes increased instability; therefore, its vertical expansion height is smaller than those of the other three landfills. The buried depth of leachate in the Xi'an landfill is the same as that in the Qizishan landfill. Fs of the vertical expansion of $40 \mathrm{~m}$ at the Qizishan landfill is greater than $F s$ of the Xi'an landfill expansion of $30 \mathrm{~m}$, which may be related to the shear strength parameters of waste. Fs of the vertical expansion of $44.2 \mathrm{~m}$ at the Quarantine Road landfill is greater than Fs of the Xi'an landfill, which may be related to the landfill and leachate level heights. The Tianziling landfill is equipped with vertical drainage wells in its expansion to reduce the leachate level and meet the stability requirements, whereas Xi'an landfill meets stability requirements using a drainage layer.

\section{Conclusions}

This case study considers leachate level and vertical expansion heights in investigating the stability of vertical expansion of an existing landfill in Xi'an, China. Combined with monitoring projects, the application of a drainage layer in the vertical expansion landfill is evaluated based on surface horizontal displacement, deep lateral displacement, and leachate levels. The following conclusions are obtained:

(1) Four slope instability modes in the vertical expansion of the landfill are categorized according to the position of the slip surface: shallow slippage of the existing landfill, shallow slippage of the expanding landfill, the interface slip between the existing landfill and the expanding landfill, and deep slippage passes through the foundation soil.

(2) The factor of safety decreases as the leachate water height increases. When the leachate level rises from $2 \mathrm{~m}$ to $20 \mathrm{~m}$, the overall factor of safety of the landfill decreases by $13.2-15.4 \%$. The overall factor of safety of the landfill decreases as the vertical expansion height increases. When the vertical expansion height increases from $0 \mathrm{~m}$ to $30 \mathrm{~m}$, the overall factor of safety of the landfill decreases by $3.5-7.7 \%$. The change range of the overall landfill factor of safety is significantly influenced by the change in the leachate level but is minimally influenced by the changes in vertical expansion height.

(3) With an increase in vertical expansion height, the stability factor of safety of the existing landfill decreases. When the height is increased by $30 \mathrm{~m}$, the stability factor of safety of the existing landfill is reduced by $4.83 \%$.

(4) After vertical expansion of the landfill was completed, the surface displacement rate did not exceed the warning value. The maximum daily displacement was $33-50 \%$ of the nonconductive layer, and the leachate level was effectively reduced.

\section{Data Availability}

The data used to support the findings of this study are included within the article.

\section{Conflicts of Interest}

The authors declare no conflicts of interest.

\section{Acknowledgments}

The research was funded by the National Natural Science Foundation of China (Contract nos. 51978625 and 51678532) and was supported by Zhejiang Provincial Natural Science Foundation of China, under Grant no. LZ21E080003. The authors would like to thank the Xi'an Landfill Group for their support.

\section{References}

[1] Y.-M. Chen and T. L. T. Zhan, "Environmental g related to landfills of municipal solid wastes," in Advances in Environmental Geotechnics, Y. Chen, L. Zhan, and X. Tang, Eds., Springer, New York, NW, USA.

[2] X. Qian, R. M. Koerner, and D. H. Gray, Geotechnical Aspects of Landfill Construction and Design, Prentice-Hall, Hoboken, NJ, USA, 2001.

[3] N. Dixon and D. R. V. Jones, "Engineering properties of municipal solid waste," Geotextiles and Geomembranes, vol. 23, no. 3, pp. 205-233, 2005.

[4] M. S. Hossain and M. A. Haque, "Stability analyses of municipal solid waste landfills with decomposition," Geotechnical \& Geological Engineering, vol. 27, no. 6, pp. 659-666, 2009.

[5] P. Ering and G. L. Sivakumar Babu, "Slope stability and deformation analysis of Bangalore MSW landfills using constitutive model," International Journal of Geomechanics, vol. 16, no. 4, Article ID 04015092, 2016.

[6] W. Gao, X.-C. Bian, W.-J. Xu, and Y.-M. Chen, "Storage capacity and slope stability analysis of municipal solid waste landfills," Journal of Performance of Constructed Facilities, vol. 32, no. 4, Article ID 04018036, 2018.

[7] Y. M. Chen, L. T. Zhan, and W. A. Lin, "Slope stability associated with expansion of MSW landfill in china," in Proceedings of the 17th International Conference on Soil Mechanics and Geotechnical Engineering, pp. 1734-1737, Alexandria, Egypt, Otober 2009.

[8] J. Roche, Modeling of a Soft Sensitive marine Silty Clay Deposit for a Landfill Expansion Study, University of New Hampshire, Durham, UK, 2006.

[9] G. Tieman, G. Druback, K. Davis, and C. Weider, "Stability consideration of vertical landfill expansions," in Geotechnics of Waste Fills-Theory and Practice. 100 Barr Harbor Drive, A. Landva and G. Knowles, Eds., ASTM International, West Conshohocken, PA, USA, 1990.

[10] Y. Chen, D. Gao, B. Zhu, and R. Chen, "Seismic stability and permanent displacement of landfill along liners," Science in China - Series E: Technological Sciences, vol. 51, no. 4, pp. 407-423, 2008.

[11] D. Choudhury and P. Savoikar, "Seismic stability analysis of expanded MSW landfills using pseudo-static limit equilibrium method," Waste Management \& Research: The Journal for a Sustainable Circular Economy, vol. 29, no. 2, pp. 135-145, 2011.

[12] F. Rong, G. Zhaogui, and F. Tugen, "Analysis of stability and control in landfill sites expansion," Procedia Engineering, vol. 24, pp. 667-671, 2011.

[13] M. F. Houlihan, C. A. Lazarte, R. D. Espinoza, A. M. German, and $\mathrm{C}$. $\mathrm{Li}$, "Use of reliability methods as a project management 
tool: the cherry island landfill expansion project," in Proceedings of the GeoFlorida 2010, American Society of Civil Engineers, West Palm Beach, FL, USA, February 2010.

[14] X.-b. Ruan, S.-1. Sun, and W.-1. Liu, "Effect of the amplification factor on seismic stability of expanded municipal solid waste landfills using the pseudo-dynamic method," Journal of Zhejiang University-Science, vol. 14, no. 10, pp. 731-738, 2013.

[15] C. Khoury, K. B. Acheampong, and K. Ofori-Awuah, "Geotechnical modeling of landfill expansion stability," in Proceedings of the 2019 Fourth International Conference on Advances in Computational Tools for Engineering Applications, pp. 1-5, ACTEA, Beirut, Lebanon, July 2019.

[16] Y. Chen, D. Gao, and B. Zhu, "Controlling strain in geosynthetic liner systems used in vertically expanded landfills," Journal of Rock Mechanics and Geotechnical Engineering, vol. 1, no. 1, pp. 48-55, 2009.

[17] H. Ke, P. Ma, J. Lan, Y. Chen, and H. He, "Field behaviors of a geogrid reinforced MSW slope in a high-food-waste-content MSW landfill: a case study," Geotextiles and Geomembranes, vol. 49, no. 2, pp. 430-441, 2021.

[18] E. Koda, A. Kiersnowska, J. Kawalec, and P. Osiński, "Landfill slope stability improvement incorporating reinforcements in reclamation process applying observational method," Applied Sciences, vol. 10, no. 5, p. 1572, 2020.

[19] D. Gupta, M. Datta, and B. Manna, "Stabilization of old MSW landfills using reinforced soil," in Lecture Notes in Civil Engineering Problematic Soils and Geoenvironmental Concerns, M. Latha Gali and P. Raghuveer Rao, Eds., Springer Singapore, Singapore, 2021.

[20] B. Munwar Basha, S. Mahapatra, and B. Manna, "Optimum dimensions of reinforced soil berm for vertical expansion of municipal solid waste (MSW) landfills," in Proceedings of the IFCEE 2015, pp. 2677-2686, American Society of Civil Engineers, San Antonio, TX, USA, March 2015.

[21] S. Mahapatra, Optimum of Reinforced Soil walls (RSW) for Vertical Expansion of MSW Landfills-A Reliability Based approach, Indian Institute of Technology Delhi, New Delhi, India, 2018.

[22] S. Mahapatra, B. M. Basha, and B. Manna, "System reliability framework for design of MSE walls for vertical expansion of MSW landfills," Journal of Hazardous, Toxic, and Radioactive Waste, vol. 25, no. 1, Article ID 04020060, 2021.

[23] B. Zhu, Y.-M. Chen, and H. Ke, "Seismic stability analysis of extended municipal solid waste landfills," Rock and Soil Mechanics, vol. 29, no. 6, pp. 1483-1488, 2008.

[24] D. Gao, B. Zhu, Y.-M. Chen, and W.-A. Liu, "Strain analysis of intermediate liner system in vertical expansion landfill," Journal of Zhejiang University, vol. 43, no. 4, pp. 760-765, 2009.

[25] L. Zhan, J. Lan, W. Li, and Y. Chen, "Slope stabilization and capacity expansion at $\mathrm{t}$ landfill in Hangzhou, China," in Proceedings of the 8th International Congress on Environmental Geotechnics, vol. 2, pp. 26-34, Hangzhou, China, October 2019.

[26] B. F. G. Tano, D. Dias, G. J. Fowmes, F. Olivier, G. Stoltz, and N. Touze-Foltz, "Numerical modeling of the nonlinear mechanical behavior of multilayer geosynthetic system for piggyback landfill expansions," Geotextiles and Geomembranes, vol. 44, no. 6, pp. 782-798, 2016.

[27] X. Qian, T.-Y. Soong, X. Zhao, and H. Shi, "Equivalent design and evaluation of the liner system for a hazardous waste landfill vertical expansion," in Proceedings of the 8th International Congress on Environmental Geotechnics, vol. 2, Hangzhou, China, October 2019.
[28] H. Jiang, X. Zhou, and Z. Xiao, "Stability of extended earth berm for high landfill," Applied Sciences, vol. 10, no. 18, p. $6281,2020$.

[29] J. Lan, Mechanism of Leachate Generation, Transport and mound in MSW Landfills and Control of Leachate Level, Zhejiang University, Hangzhou, China, 2012.

[30] R. Yang, Z. Xu, and J. Chai, "Seepage analysis of a multilayer waste slope considering the spatial and temporal domains of permeability," Advances in Civil Engineering, vol. 2019, Article ID 3689097, 10 pages, 2019.

[31] J.-E. Min, M. Kim, J. Y. Kim, I.-S. Park, and J.-W. Park, "Leachate modeling for a municipal solid waste landfill for upper expansion," KSCE Journal of Civil Engineering, vol. 14, no. 4, pp. 473-480, 2010.

[32] H. He, J. Lan, Y. Chen et al., "Application and analysis of drainage well in landfill slip control," Chinese Journal of Geotechnical Engineering, vol. 39, no. 5, pp. 813-821, 2017.

[33] H. Ke, J. Hu, X. W. Wu, and M. Meng, "Investigation into leachate transport in MSW landfills under pumping of vertical wells," Chinese Journal of Geotechnical Engineering, vol. 40, no. 5, pp. 786-793, 2018.

[34] J. Ye, J. Lan, Y. Chen, H. Ke, and K.-H. Wang, "Seepage model and spacing design of horizontal trench in landfills," Chinese Journal of Geotechnical Engineering, vol. 38, no. 10, pp. 1923-1926, 2016.

[35] R. P. Beaven, S. E. Cox, and W. Powrie, "Operation and performance of horizontal wells for leachate control in a waste landfill," Journal of Geotechnical and Geoenvironmental Engineering, vol. 133, no. 8, pp. 1040-1047, 2007.

[36] N. Maeda, J. Tsukahara, K. Endo, M. Kamon, and T. Katsumi, "Seashore MSW landfill using drainage layer and thick soil cover-leachate containment and post-closure land use," in Proceedings of the 8th International Congress on Environmental Geotechnics, vol. 1, pp. 804-811, Hangzhou, China, October 2019.

[37] M. Dang, J. Chai, Z. Xu, Y. Qin, J. Cao, and F. Liu, "Soil water characteristic curve test and saturated-unsaturated seepage analysis in Jiangcungou municipal solid waste landfill, China," Engineering Geology, vol. 264, Article ID 105374, 2020.

[38] H. Liu, Research on Biodegradation-Consolidation-Solute Migration Coupled Behaviors of Municipal Solid Waste and Landfill Stabilization, Zhejiang University, Hangzhou, China, 2016.

[39] O. Mohr, "Welche Umstnde bedingen die Elastizitsgrenze und den Bruch eines Materials?" Zeit des Ver Deut Ing, vol. 44, pp. 1524-1530, 1900.

[40] R. Yang, Study on the Heterogeneous Property and Seepage Field and Slope Stability of Waste Pile in Municipal Solid Waste Landfill, Xi'an University of Technology, Xi'an, China, 2020.

[41] A. W. Bishop, "The use of the slip circle in the stability analysis of slopes," Géotechnique, vol. 5, no. 1, pp. 7-17, 1955.

[42] E. Spencer, "A method of analysis of the stability of embankments assuming parallel inter-slice forces," Géotechnique, vol. 17, no. 1, pp. 11-26, 1967.

[43] N. R. Morgenstern and V. E. Price, "The analysis of the stability of general slip surfaces," Géotechnique, vol. 15, no. 1, pp. 79-93, 1965.

[44] X. Qian, R. M. Koerner, and D. H. Gray, "Translational failure analysis of landfills," Journal of Geotechnical and Geoenvironmental Engineering, vol. 129, no. 6, pp. 506-519, 2003.

[45] S. Feng, Y. Chen, and G. Gao, "Analysis on translational failure of landfill along the underlying liner system," Chinese 
Journal of Geotechnical Engineering, vol. 29, no. 1, pp. 20-25, 2007.

[46] R. M. Koerner and T.-Y. Soong, "Stability assessment of ten large landfill failures," Advances in Transportation and Geoenvironmental Systems Using Geosynthetics, Vol. 1-38, American Society of Civil Engineers, Denver, CO, USA, 2000.

[47] T. D. Stark, H. T. Eid, W. D. Evans, and P. E. Sherry, "Municipal solid waste slope failure. II: stability analyses," Journal of Geotechnical and Geoenvironmental Engineering, vol. 126, no. 5, pp. 408-419, 2000.

[48] J. Liu and X. Kong, "Seismic stability and permanent displacement analysis of a solid waste landfill slope containing geomembrane," Rock and Soil Mechanics, vol. 25, no. 5, pp. 778-782, 2004.

[49] X. Wang, W. Zou, and R. Zhu, "Stability analysis of cover soil slope on waste landfill under seepage with limit equilibrium method," Chinese Journal of Rock Mechanics and Engineering, vol. 23, no. 11, pp. 1939-1943, 2004.

[50] E. Durmusoglu, M. Y. Corapcioglu, and K. Tuncay, "Modeling of settlement in saturated and unsaturated municipal landfills," International Journal of Geomechanics, vol. 6, no. 4, pp. 269-278, 2006.

[51] J. McDougall, "A hydro-bio-mechanical model for settlement and other behaviour in landfilled waste," Computers and Geotechnics, vol. 34, no. 4, pp. 229-246, 2007.

[52] S. L. Machado, O. M. Vilar, and M. F. Carvalho, "Constitutive model for long term municipal solid waste mechanical behavior," Computers and Geotechnics, vol. 35, no. 5, pp. 775-790, 2008.

[53] J. Bauer, F. Koelsch, and A. V. A. Borgatto, Stability Analysis According to Different Shear Strength Concepts Exemplified by Two Case Studies, Technical University of Braunschweig, Braunswick, Germany, 2008.

[54] X. Qian and R. M. Koerner, "Stability analysis when using an engineered berm to increase landfill space," Journal of Geotechnical and Geoenvironmental Engineering, vol. 135, no. 8, pp. 1082-1091, 2009.

[55] W. Zhang, W. Liu, and Y. Chen, "Pore pressure monitoring and slope stability analysis of A waste landfill," Chinese Journal of Rock Mechanics and Engineering, vol. 29, no. S2, pp. 3628-3632, 2010.

[56] D. Turer and A. Turer, "A simplified approach for slope stability analysis of uncontrolled waste dumps," Waste Management \& Research: The Journal for a Sustainable Circular Economy, vol. 29, no. 2, pp. 146-156, 2011.

[57] G. Varga, "Some geotechnical aspects of bioreactor landfills," Periodica Polytechnica: Civil Engineering, vol. 55, no. 1, p. 39, 2011.

[58] B. M. Basha and S. Mahapatra, "Reliability based design of municipal solid waste (MSW) landfills using translational failure mechanism," in Proceedings of the Geo-Congress 2013, pp. 1034-1043, American Society of Civil Engineers, San Diego, CA, USA, March 2013.

[59] J. Shi and J.-L. Luan, "Stability analysis method for composite failure through base liner and waste filling," Rock and Soil Mechanics, vol. 34, no. 9, pp. 2576-2582, 2013.

[60] S. L. Sun and X. B. Ruan, Environmental Earth Sciences, vol. 68, no. 5, pp. 1465-1473, 2013.

[61] R. K. Giri and K. R. Reddy, "Slope stability of bioreactor landfills during leachate injection: e," Waste Management \& Research: The Journal for a Sustainable Circular Economy, vol. 32, no. 3, pp. 186-197, 2014.

[62] H. Zhang, M. Huang, and H. Wang, "3D stability numerical analysis of landfill considering the leachate level," Chinese
Journal of Underground Space and Engineering, vol. 10, no. S2, pp. 2000-2005, 2014.

[63] X. Fan, M. Huang, and H. Wang, "Stability analysis of a municipal solid waste slope layered by aging," Rock and Soil Mechanics, vol. 37, no. 6, pp. 1715-1720, 2016.

[64] L. Batali, A. Carastoian, H. Popa, and G. Pantel, "Instability phenomena in municipal waste landfill. Numerical modeling in saturated and unsaturated conditions," Energy Procedia, vol. 112, pp. 481-488, 2017.

[65] A. Jahanfar, M. Amirmojahedi, B. Gharabaghi, B. Dubey, E. McBean, and D. Kumar, "A novel risk assessment method for landfill slope failure: case study application for Bhalswa Dumpsite, India," Waste Management \& Research: The Journal for a Sustainable Circular Economy, vol. 35, no. 3, pp. 220-227, 2017.

[66] Q. Zhang, Y. Wang, Y. Xu, and R. Li, "Key geotechnical problems in the reconstruction and expansion of existing MSW landfills," China Civil Engineering Journal, vol. 40, no. 4, pp. 73-81, 2007.

[67] R. P. Stulgis, C. Soydemir, R. J. Telgener, and R. D. Hewitt, "Use of geosynthetics in 'piggyback landfills': a case study," Geotextiles and Geomembranes, vol. 14, no. 7-8, pp. 341-364, 1996.

[68] J. Li, B. Zhu, C. Yang, L. Wang, and Y.-M. Chen, "Centrifugal model tests on stress deformation of plain-type landfills under vertical expansion," Rock and Soil Mechanics, vol. 39, no. 11, pp. 4071-4078+4085, 2018.

[69] Z. Zhang, Y. Wang, Y. Fang, X. Pan, J. Zhang, and H. Xu, "Global study on slope instability modes based on $62 \mathrm{mu}-$ nicipal solid waste landfills," Waste Management \& Research: The Journal for a Sustainable Circular Economy, vol. 38, no. 12, pp. 1389-1404, 2020.

[70] R. J. Byrne, J. Kendall, and S. Brown, "Cause and mechanism of failure Kettleman hills landfill B-19, phase IA," Stability and Performance of Slopes and Embankments II, ASCE, Virginia, NV, USA, 1992.

[71] G. M. Filz, J. J. B. Esterhuizen, and J. M. Duncan, "Progressive failure of lined waste impoundments," Journal of Geotechnical and Geoenvironmental Engineering, vol. 127, no. 10, pp. 841-848, 2001.

[72] H. T. Eid, T. D. Stark, W. D. Evans, and P. E. Sherry, "Municipal solid waste slope failure. I: waste and foundation soil properties," Journal of Geotechnical and Geoenvironmental Engineering, vol. 126, no. 5, pp. 397-407, 2000.

[73] National Building Research Organisation, Geotechnical Assessment on the Failure at Meethotamulla Waste Fill, Ministry of Disaster Management, Colombo, Sri Lanka, 2017.

[74] T. L. T. Zhan, Y. M. Chen, and W. A. Ling, "Shear strength characterization of municipal solid waste at the Suzhou landfill, China," Engineering Geology, vol. 97, no. 3-4, pp. 97-111, 2008. 